\title{
GC-MS of essential oil, metal profile and physicochemical properties of fruits of Citrus macrophylla Wester from Sudan
}

\author{
Abdelhafeez M. A. Mohammed ${ }^{1,2^{*}} \mathbb{0}$, Alrayeh S. Alrayeh², Moawia E. Mohamed ${ }^{3}$ and Nawal A. Abdel-Rahman ${ }^{4}$
}

\begin{abstract}
Background: The study investigated the essential oil composition, metal profile and physiochemical properties of Citrus macrophylla Wester fruits collected from Agricultural Research Corporation, Shambat area, Khartoum North, Sudan. The species was introduced by one of the authors Dr. Moawia E. Mohamed from the National Repository of Citrus and Dates of Riverside, California, USA. This species is known as universal rootstock.

Results: The graphite furnace-atomic absorption spectrometry determined the presence of sodium ( $6.38 \mathrm{ppm}$ ), potassium (701.93 ppm), calcium (371.28 ppm), magnesium (54.78 ppm), cadmium (0.013 ppm), zinc (0.256 ppm) and lead (0.200 ppm). The content of peel, moisture and ash of C. macrophylla was measured as $18.35 \%, 23.75 \%$ and $2.04 \%$, respectively. Among thirty compounds identified using gas chromatography-mass spectrometry, limonene is the major compound (72.85\%). The vitamin C (ascorbic acid) content of C. macrophylla juice was determined as $55.0 \mathrm{mg} / 100 \mathrm{~g}$. The fruit diameter, fruit weight and percentages of juice, peel and seed were determined as $91.4 \mathrm{~mm}$, $276.5 \mathrm{~g}, 47.92 \%, 26.37 \%$ and $19.20 \%$, respectively. The pH value, total soluble solids (TSS), titratable acidity (TA) and ripening index (RI) of C. macrophylla are found to be $3.50,8.00 \%, 7.44 \%$ and 10.81 , respectively.
\end{abstract}

Conclusion: The results in this study suggested that C. macrophylla could be beneficial in food as healthy juice.

Keywords: Essential oils, GC-MS, GF-AAS, Citrus macrophylla, Rutaceae

\section{Background}

The genus Citrus L. is belonging to the family Rutaceae. This family comprises 140 genera and 1300 species (Anwar et al. 2008). The genus, Citrus, has a variety of limes, lemons, oranges, grape fruits and mandarins. The Citrus species is widely cultivated as a popular fruit worldwide (Abbasi et al. 2009) and indigenous to the tropical and subtropical regions of Asia as well as Malaysian Islands (Singh and Singh 2002). As the world's most widely grown fruit crop, Citrus fruits made mainly for their juice, one of their most important products, and their essential oils.

\footnotetext{
*Correspondence: ahafeez61@yahoo.com; amamohamad@kau.edu.sa

${ }^{1}$ Department of Chemistry, Rabigh College of Science \& Arts, King

Abdulaziz University, PO Box 344, Rabigh 21911, Saudi Arabia

Full list of author information is available at the end of the article
}

The essential oils of Citrus are mainly utilized as flavoring by a variety of food industries (Dharmawan et al. 2008). The essential oils of Citrus fruits are widely used in the perfume and fragrance industry, food industries such as sweet and juice flavorings. In addition, they are used as components of pharmaceuticals, antiseptics and aromatherapy products. Citrus oils are utilized in beauty products, deodorants, soaps and detergents (El-Adawy et al. 1999; Silalahi 2002; Saïdani et al. 2004). The recent study analyzed the oil of Citrus sinensis L. using GC-MS showing that ninety-six compounds identified from eight plant species and representing $99 \%$ of the total oil. Limonene was the major component in all samples (59.53-95.34\%) (Zouaghi et al. 2019). Normally the Citrus fruits accumulate abundant of very important bioactive compounds that may affect human health. These bioactive compounds include essential oils, vitamin $\mathrm{C}$ (ascorbic 
acid), terpenes, flavonoids, alkaloids, fibers and minerals (Hamdan et al. 2011). Therefore, the efficacy of medicinal plants for curative purpose is due to the presence of bioactive components. But it is noticed that over-dose or prolonged injection of medicinal plants leads to accumulation of different elements which in turns cause various health problems (Sharma et al., 2009). The Citrus peel, often treated as agricultural pollutant, can be a potent source of plant metabolites and essential oils (Mohammed et al. 2013).

In Sudan, Citrus fruits are most important tree crops. The Sudanese peoples cultivated Citrus species for their edible fruits which include C. aurantifolia Swingle (lime), C. sinensis L. (sweet orange), C. aurantium L. (sour orange), C. reticulata Blanco (mandarin) and C. paradise Macf (grape fruit). In addition, C. macrophylla Webster. (Alemow) and C. jambhiri Lush (rough lemon) were introduced and cultivated recently in the field of Agricultural Research Corporation, Shambat area, Khartoum North, Sudan, by one author of the current study (M.E. Mohamed). The major component of essential oil of Citrus jambhiri and Citrus macrophylla is limonene which was determined previously in high amounts $55.4 \%$ and $60.7 \%$, respectively (Robbins et al. 2012; Aguilar-Hernández et al. 2020).

Although macroelements are essential for plants, they may produce toxins that affect human health if taken in high concentrations, while microelements are toxic even in low concentrations. Therefore, the metal content of medicinal plants should be tested in order to control their qualities and nutritional values. Nowadays, numerous studies around the world have highlighted the importance of herbs for herbal medicines that have raised awareness of trace elements in these plants (Gebrelibanos et al. 2016).

In traditional or herbal medicine, using medicinal plants for long periods or in over-dose will accumulate elements that have serious health problems. Therefore, the authentication and quality control of medicinal plants should be investigated in order to link the chemistry of these plants with their medicinal uses. Therefore, researchers run after finding the right dose of supplement in the proper form at the right time (Sharma et al. 2009; Arceusz et al. 2010).

Citrus macrophylla, commonly known as Alemow, is a universal rootstock (Castle et al. 2009). Since this species is known to be a rootstock, most of the researches done on it from horticultural aspects such as cultural practices and physical features. The more recent study on the peel oil of Citrus macrophylla using GC-MS technique showed that twenty-six compounds were identified. Limonene was found to be the major component (Aguilar-Hernández et al. 2020).
To the best of our knowledge, the current research is the first study on the fruit of Citrus macrophylla as edible and to evaluate its nutritional value. The presence of toxic heavy metals such as $\mathrm{Pb}$ has detrimental effect on human health even in low concentration. The permissible limit of $\mathrm{Pb}$ in Citrus fruit is $0.10 \mathrm{ppm}$ according to $\mathrm{FAO} /$ WHO (FAO/WHO 2011). Therefore, elemental analysis of fruit is an important part to investigate, in addition to vitamin $C$ content. Surveying the literature and to the best of our knowledge, none of the macro- or microelement has been determined quantitatively in Citrus macrophylla except sodium and potassium in a single study (Levy and Lifshitz 1995). Accordingly, this study will add novel knowledge in evaluation of nutritional value of this species as an edible plant. Therefore, the main objective of this study is to investigate the macroelements $(\mathrm{K}, \mathrm{Na}$, $\mathrm{Ca}$ and $\mathrm{Mg}$ ) and microelements $(\mathrm{Zn}, \mathrm{Co}, \mathrm{Ni}, \mathrm{Cd}, \mathrm{Pb}, \mathrm{Cr}$ and $\mathrm{Fe}$ ) levels in C. macrophylla, in addition to the physiochemical properties and the chemistry of peel essential oil.

\section{Methods \\ Plant material}

The fruits of C. macrophylla are collected from Agricultural Research Corporation, Shambat area, Khartoum North, Sudan, in May 2016 at $35{ }^{\circ} \mathrm{C}$ and humidity of $8 \%$ (Fig. 1). The species is introduced by one of the authors Dr. Moawia E. Mohamed from the National Repository of Citrus and Dates of Riverside, California, USA. This collection is kept at Shambat Research Station (Mohamed and ElTayeb 2009). The voucher specimen is deposited in Herbarium of Botany Department, Faculty

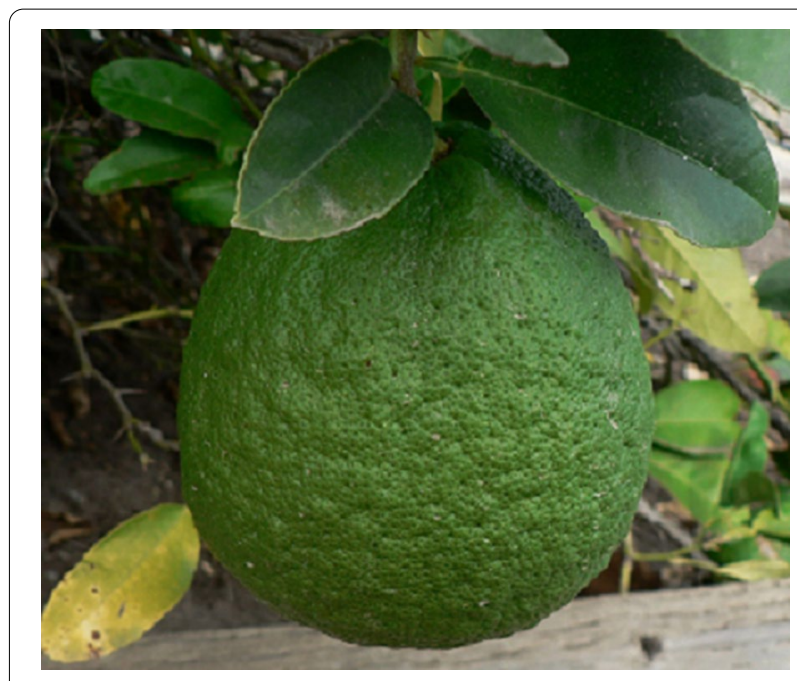

Fig. 1 Photograph of Citrus macrophylla fruit (Photo by First Author) 
of Science, University of Khartoum, Sudan, for the purpose of verification.

\section{Physiochemical properties of fruit}

The granular size of fresh fruits of C. macrophylla is recorded using Vernier Calipers (model: EHB Stainless, Hardened, Germany). In addition, the weight of fruit, juice, peel and seed are measured using a top loading balance (model: D0001-H R 120, A \& D Company Ltd EC). Vitamin $C$ content of $C$. macrophylla juice was determined by titrimetry using 2,6-dichlorophenolindophenol (DCPIP) assay (Nielsen 2010).

\section{Extraction of essential oil and fruit juice}

The maceration of fresh peel of C. macrophylla using $n$-hexane $(3 \times 2 \mathrm{~L})$ for $48 \mathrm{~h}$ at room temperature leads to extraction of essential oil after evaporating $n$-hexane by a rotator evaporator at $30^{\circ} \mathrm{C}$, then followed by evaporation of solvent under reduced pressure (Maimulyanti and Anton 2016). The crude oil was used for GC-MS analysis. The traditional method of juice extraction was carried out to extract fruit juice (Beveridge and Rao 1997).

\section{GC-MS analysis of the essential oil}

The GC-MS analysis of the peel essential oil of C. macrophylla was carried out using gas chromatography-mass spectrometry instrument at the Department of Medicinal and Aromatic Plants Research, National Research Centre, Egypt, with the following specifications. Instrument: a TRACE GC Ultra Gas Chromatographs (THERMO Scientific Corp., USA), coupled with a THERMO mass spectrometer detector (ISQ Single Quadrupole Mass Spectrometer). The GC-MS system was equipped with a TG-5MS column $(30 \mathrm{~m} \times 0.25 \mathrm{~mm}$ i.d., $0.25 \mu \mathrm{m}$ film thickness). Analyses were carried out using helium as carrier gas at a flow rate of $1.0 \mathrm{ml} / \mathrm{min}$ and a split ratio of 1:10 using the following temperature program: $60^{\circ} \mathrm{C}$ for $1 \mathrm{~min}$; rising at $3.0^{\circ} \mathrm{C} / \mathrm{min}$ to $240{ }^{\circ} \mathrm{C}$ and held for $1 \mathrm{~min}$. The injector and detector were held at $240{ }^{\circ} \mathrm{C}$. Diluted samples (1:10 hexane, $\mathrm{v} / \mathrm{v})$ of $0.2 \mu \mathrm{L}$ of the mixtures were always inject. Mass spectra were obtained by electron ionization (EI) at $70 \mathrm{eV}$, using a spectral range of $\mathrm{m} / \mathrm{z}$ 40-450. Most of the compounds were identified using the analytical method: mass spectra (authentic chemicals, Wiley spectral library collection and NSIT library).

\section{Metal profile}

The determination of metal profile was achieved using Varian Spectra AA 220FS Atomic Absorption Spectrometer (AAS) at the laboratories of Ministry of Mining, Sudan. Exactly $17.01 \mathrm{~g}$ of the fresh fruit of C. macrophylla in a crucible was heated in an oven at $105{ }^{\circ} \mathrm{C}$ for $3 \mathrm{~h}$ until constant weight. Then, the moisture content was obtained by weight loss difference (AOAC 1990). For ash content, the dried material was heated in the muffle furnace at $450^{\circ} \mathrm{C}$ for $3 \mathrm{~h}$ until constant weight obtained and the ash content was calculated. For elemental analysis, an accurate weight of ash was digested using concentrated nitric acid and filtered through Whatman filter paper and the filtrate was completed to a certain volume for chemical analysis using atomic absorption spectrometer (AAS) (AOAC 1990).

Using 2,6-dichlorophenolindophenol (DCPIP) assay, vitamin $C$ (ascorbic acid) content of C. macrophylla juice was determined (Nielsen 2010). The total soluble solids (TSS) of fruits were measured with a handheld Refractometer $(0-50 \%$ Brix $)$ at $20{ }^{\circ} \mathrm{C}$ and were expressed as percentage (\%) or degree Brix $\left({ }^{\circ} \mathrm{Bx}\right)$ (AOAC 1990).

The $\mathrm{pH}$ value was measured with a glass electrode pH-meter (model: HANNA Instrument 8521 Portugal) at ambient temperature. The titratable acidity (TA) was determined on neutralization of $0.1 \mathrm{NaOH}$ to end (pink color) with citric acid. The ripening index (RI) was calculated as ratio of TSS/TA (Ranganna 1986; Legua et al. 2011).

\section{Results}

\section{Physiochemical properties}

The physiochemical parameters of fruit of C. macrophylla were determined, and the results are presented in Table 1. These parameters include the juice, peel and seed percentages, in addition to size, weight, dimension, diameter, moisture, ash content, vitamin

Table 1 Physiochemical properties of C. macrophylla and fruit juice $(n=3)$

\begin{tabular}{llll}
\hline Parameter (unit) & Mean & SD & Reference \\
\hline Fruit length/height (mm) & 85.9 & 0.2000 & $(76.76)^{\mathrm{a}}$ \\
$\begin{array}{l}\text { Fruit width (diameter, } \\
\text { mm) (mm) }\end{array}$ & 91.4 & 0.2750 & $(79.92)^{\mathrm{a}}$ \\
Fruit thickness (mm) & 92.2 & 0.3750 & \\
Fruit weight (g) & 276.5 & $0.5000 \quad(235.09)^{\mathrm{a}}$ \\
Juice weight & $132.5 \mathrm{~g}(47.92 \%)$ & 0.2658 & $(44.24 \%)^{\mathrm{a}}(54.3 \%)^{\mathrm{b}}$ \\
Peel & $72.9 \mathrm{~g}(26.37 \%)$ & 0.0020 & \\
Seed & $53.1 \mathrm{~g}(19.20 \%)$ & 0.2020 \\
Moisture (\%) & 26.4 & 0.1230 \\
Ash (\%) & 3.08 & 0.0100 \\
Vitamin C (mg/100 g) & 55.0 & 0.2500 & $(47.0)^{\mathrm{a}}$ \\
pH-value & 3.50 & 0.0100 & $(4.00)^{\mathrm{a}}$ \\
Total soluble solids (TSS) & 9.30 & $0.0800 \quad(10.6)^{\mathrm{a}, \mathrm{b}}$ \\
(\%) & & & \\
Titratable acidity (TA) (\%) & 0.74 & 0.0050 & $(0.66)^{\mathrm{a}}(1.23)^{\mathrm{b}}$ \\
Ripeness index (RI) & 14.81 & $0.0780 \quad(16.0)^{\mathrm{a}}$
\end{tabular}

${ }^{a}$ Legua et al. (2011)

${ }^{\mathrm{b}}$ Levy and Lifshitz (1995) 
$\mathrm{C}$ content, of the fruit. In addition, the average values of pH, TSS, TA and RI of fruit juice were determined experimentally.

The juice, peel and seed percentages were determined as $47.92 \%, 26.37 \%$ and $19.20 \%$, respectively. The dimensions of the fruit of C. macrophylla are found to be $85.9 \mathrm{~mm}, 91.4 \mathrm{~mm}$ and $92.2 \mathrm{~mm}$ for length, width (diameter) and thickness, respectively. The weight of fruit of $C$. macrophylla was experimentally determined as $276.5 \mathrm{~g}$ compared to $235.09 \mathrm{~g}$ reported before for C. macrophylla (Legua et al. 2011).

The moisture content of fruit of C. macrophylla was recorded as $26.4 \%$. The ash content was determined as $3.08 \%$. There are no previous studies on C. macrophylla for moisture and ash contents, but the current results are reasonable when compared to those of other species of Citrus (Azad et al. 2014; Ani and Abel 2018). Vitamin C (ascorbic acid) content was found to be $55.0 \mathrm{mg} / 100 \mathrm{~g}$, which is in a good agreement with reported results 0.047\% (modified to $47.0 \mathrm{mg} / 100 \mathrm{~g}$ ) (Legua et al. 2011).

Table 1 shows the average values of $\mathrm{pH}$, TSS, TA and RI of fruit juice of C. macrophylla as 3.50, 9.30\%, 0.74\% and 14.81, respectively. These results were in a good agreement with the previous study by Legua et al. (2011). Titratable acidity (TA) refers to the total concentration of titratable acids in a sample (Berezin et al. 1995). In this study, TA was found as $0.74 \%$.

\section{Chemical composition of peel essential oil}

The chemical composition of essential oil of C. macrophylla peel was determined by using gas chromatography-mass spectrometry (GC-MS). The results presented in Table 2 revealed that the essential oil consists of a mixture of thirty compounds in which limonene is the major and most abundant compound (72.85\%), followed by $\gamma$-terpinene (13.44\%) in addition to many other

Table 2 Percentages of volatile compounds in C. macrophylla peel oils

\begin{tabular}{|c|c|c|c|c|}
\hline No & Compound & Rt (min.) & Compound class & Rel. (\%) \\
\hline 1 & a-Phellandrene & 4.57 & Monoterpene & 0.42 \\
\hline 2 & a-Pinene & 4.76 & $"$ & 1.94 \\
\hline 3 & Sabinene & 4.79 & $"$ & 0.28 \\
\hline 4 & $\beta$-Pinene & 5.96 & $"$ & 1.05 \\
\hline 5 & $\beta$-Myrcene & 6.22 & $"$ & 1.57 \\
\hline 6 & p-Cymene & 7.44 & Aromatic hydrocarbon & 0.23 \\
\hline 7 & Limonene & 7.55 & Monoterpene & 72.85 \\
\hline 8 & cis-Ocimene & 7.72 & $"$ & 1.94 \\
\hline 9 & a-Ocimene & 8.08 & $"$ & 1.00 \\
\hline 10 & y-Terpinene & 8.54 & $"$ & 13.44 \\
\hline 11 & Linalool oxide & 9.07 & $"$ & 0.17 \\
\hline 12 & Hexachoroethane & 9.20 & Aliphatic alkane & 0.10 \\
\hline 13 & Linalool & 10.22 & Monoterpene & 0.29 \\
\hline 14 & 1,3-Dimethyladamantane & 10.88 & Cyclolkane & 0.58 \\
\hline 15 & 1,3-Dimethyl-5-ethyladamantane & 11.18 & $"$ & 0.10 \\
\hline 16 & Decahydro-2,3-dimethylnaphthalene & 12.82 & Aromatic hydrocarbon & 0.29 \\
\hline 17 & 1,4-Dimethyladamantane & 13.56 & Cyclolkane & 0.22 \\
\hline 18 & a-Terpineol & 14.22 & Monoterpene & 0.32 \\
\hline 19 & Linalyl propionate & 14.22 & Ester & 0.32 \\
\hline 20 & 1,2-Dimethyl-5-nitroadamantane & 16.26 & Cyclolkane & 0.19 \\
\hline 21 & -Elemene & 19.65 & Sesquiterpene & 0.08 \\
\hline 22 & trans-Caryophyllene & 23.18 & $"$ & 0.63 \\
\hline 23 & trans-a-Bergamotene & 23.75 & $"$ & 0.78 \\
\hline 24 & a-Humulene & 24.70 & $"$ & 0.10 \\
\hline 25 & Germacrene D & 25.76 & $"$ & 1.01 \\
\hline 26 & Y-Elemene & 26.33 & $"$ & 0.24 \\
\hline 27 & $\beta$-Bisabolene & 26.94 & $"$ & 0.49 \\
\hline 28 & Ledene (Veridiflorol) & 30.03 & $"$ & 0.07 \\
\hline 29 & Junipene (Longifolene) & 30.03 & $"$ & 0.08 \\
\hline 30 & Ledol (a-Santalene) & 32.93 & $"$ & 0.07 \\
\hline
\end{tabular}


compounds. The essential oil was characterized by the presence of monoterpene as a main class (96.0\%), in addition to other classes of components such as sesquiterpenes $(1.32 \%)$, hydrocarbons $(1.09 \%)$, esters $(0.32 \%)$ and aromatics $(0.52 \%)$.

\section{Metal profile}

The results of metal profile of C. macrophylla fruit are presented in Table 3 . The concentration of potassium (K) was found as $701.93 \mathrm{ppm}$ compared to $1567.91 \mathrm{ppm}$ (modified unit) in only single previous study. The concentration of sodium $(\mathrm{Na})$ in fruit of C. macrophylla was found to be $6.38 \mathrm{ppm}$ compared to $7.35 \mathrm{ppm}$ in previous study which is in good agreement (Levy and Lifshitz 1995). The concentration of calcium (Ca) in fruit of $C$. macrophylla was found to be $371.28 \mathrm{ppm}$.

The concentration of magnesium $(\mathrm{Mg})$ in fruit of $C$. macrophylla was found to be $54.78 \mathrm{ppm}$. The concentrations of cadmium $(\mathrm{Cd})$ and lead $(\mathrm{Pb})$ in fruit of C. macrophylla were found to be $0.013 \mathrm{ppm}$ and $0.200 \mathrm{ppm}$, respectively. The concentration of zinc $(\mathrm{Zn})$ in fruit of C. macrophylla was found to be $0.256 \mathrm{ppm}$. Although iron (Fe), nickel (Ni), cobalt (Co) and chromium $(\mathrm{Cr})$ are known as essential elements for plant growth, in the current study, none of these elements were detected.

\section{Discussion}

The physiochemical parameters of fruit of C. macrophylla were determined including the juice, peel and seed percentages, in addition to size, weight, dimension, diameter, moisture, ash content, vitamin $\mathrm{C}$ content, of the fruit. In addition, the average values of $\mathrm{pH}$, TSS, TA and $\mathrm{RI}$ of fruit juice were determined experimentally.

Table 3 Metal profile of C. macrophylla fruit in (ppm) $(n=3)$

\begin{tabular}{clll}
\hline Element & Mean & SD & Reference \\
\hline Macroelements & & & \\
$\mathrm{K}$ & 701.93 & 0.3600 & $1567.91^{\mathrm{a}}$ \\
$\mathrm{Na}$ & 6.38 & 0.8200 & $7.35^{\mathrm{a}}$ \\
$\mathrm{Ca}$ & 371.28 & 0.5000 & \\
$\mathrm{Mg}$ & 54.78 & 0.2100 & \\
$\mathrm{Microelements}$ & & & \\
$\mathrm{Cd}$ & 0.013 & 0.0684 & \\
$\mathrm{Zn}$ & 0.256 & 0.0090 & \\
$\mathrm{~Pb}$ & 0.200 & 0.0010 & \\
$\mathrm{Fe}$ & $\mathrm{ND}$ & $\mathrm{ND}$ & \\
$\mathrm{Co}$ & $\mathrm{ND}$ & $\mathrm{ND}$ & \\
$\mathrm{Ni}$ & $\mathrm{ND}$ & $\mathrm{ND}$ & \\
$\mathrm{Cr}$ & $\mathrm{ND}$ & $\mathrm{ND}$ & \\
\hline
\end{tabular}

ND, not detected

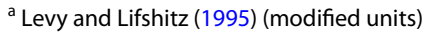

The juice percentage obtained in the current study is in a good agreement with the published work (Levy and Lifshitz 1995; Legua et al. 2011). The length, width (diameter) and thickness of the fruit of C. macrophylla were determined. The diameter of fruit of C. macrophylla is to some extent larger than for fruit of the same species studied by Legua et al. (2011). The weight of fruit of $C$. macrophylla is more or less the same as that reported before (Legua et al. 2011). The moisture and ash contents of fruit of C. macrophylla were determined, but there are no previous studies on $C$. macrophylla to compare with. The current results are reasonable when compared to those of other species of Citrus (Azad et al. 2014; Ani and Abel 2018).

Vitamin C (ascorbic acid) content was found to be higher the reported study. So, Citrus macrophylla is a rich in vitamin $C$ (Legua et al. 2011). The average values of pH, TSS, TA and RI of fruit juice of C. macrophylla were in a good agreement with the previous study by Legua et al. (2011). The importance of RI is normally been used as a marker of maturation of fruits (Levy and Lifshitz 1995; Legua et al. 2011). Titratable acidity (TA) refers to the total concentration of titratable acids in a sample, and it is an important characteristic of the quality of numerous products such as vegetable oils, juices, wines, petroleum, motor oils and others (Berezin et al. 1995). The parameters fruit size, juice content, TSS (total soluble solids) and TA (titratable acidity) are important in establishing marketing standards for fruits (FornerGiner et al. 2003).

The chemical composition of essential oil of C. macrophylla peel was performed by using gas chromatography-mass spectrometry (GC-MS) technique. The essential oil consists of a mixture of thirty compounds in which limonene is the major and most abundant compound, followed by $\gamma$-terpinene, in addition to many other compounds. The essential oil was characterized by the presence of monoterpenes as a main component in this plant species in addition to sesquiterpenes, hydrocarbons, esters and aromatics. Comparison to the literature, these results were to some extent are similar to previous studies (Verzera et al. 2003; Robbins et al. 2012; Navarra et al. 2015; González-Mas et al. 2019; Zouaghi et al. 2019; Aguilar-Hernández et al. 2020). The presence of high percentage of monoterpenes and high concentration of vitamin $C$ encourages people to use this species as a medicinal herb.

Using graphite furnace-atomic absorption spectrometry (GF-AAS) technique determines metal profile of $C$. macrophylla fruit. Because of its diuretic nature, potassium $(\mathrm{K})$ is one of the most important elements for living organism and this plant species contain considerable amount of it. The concentration of sodium $(\mathrm{Na})$ in fruit 
of C. macrophylla was found to be in good agreement compared to previous study (Levy and Lifshitz 1995). In general, high concentration of sodium in edible fruits is not recommended although it has a role in the transport of metabolites. High sodium intake has been proven that it increases hypertension (Paul and Shaha 2004).

To the best of knowledge, no previous study on the concentration of calcium (Ca) in fruit of C. macrophylla was carried out, but when comparing our result to other Citrus species it is in a good agreement. The presence of $\mathrm{Ca}$ in high amounts is very important in bones, teeth, muscles and heart functions (Czech et al. 2020). Magnesium $(\mathrm{Mg})$ is an essential element in biological systems and found as an ion $\left(\mathrm{Mg}^{2+}\right)$ that reacts with adenosine triphosphate (ATP) in order to be biologically active. Magnesium intake has an important role in strengthening muscles central nervous system (CNS) (Czech et al. 2020). Fortunately, the concentration of magnesium (Mg) in fruit of C. macrophylla was found to be reasonable compared to other Citrus species since there is no previous study of magnesium in C. macrophylla. There is no previous study on concentration of cadmium $(\mathrm{Cd})$ and lead $(\mathrm{Pb})$ in fruit of C. macrophylla to the best of our knowledge. Both cadmium and lead are known for their toxicity in food and in turn cause serious effects on kidney, liver and immune system of human (Sheded et al., 2006). This is the first time to determine the concentration of zinc $(\mathrm{Zn})$ in fruit of C. macrophylla. Zinc is an important nutritional element. The zinc deficiency is a main reason for health problem especially in children resulting in stunted children in developing countries (FAO/WHO 1984Sian et al. 2002; Osendarp et al., 2003). Although iron (Fe), nickel (Ni), cobalt (Co) and chromium $(\mathrm{Cr})$ are known as essential elements for plant growth, in the present study none of these elements were detected. The permissible limit of iron (Fe) set by FAO/ WHO for edible plants is $20.0 \mathrm{ppm}$ (FAO/WHO 1984). Iron is required for the formation of hemoglobin and its role in the transfer of oxygen and electron to the human body, the normal functioning of the CNS. In addition, it has a role in oxidation of carbohydrates, proteins and fats. Anemia recognition in Fe secretion may be related to its role in facilitating iron uptake and iron uptake into hemoglobin (FAO/WHO 1984).

\section{Conclusions}

Citrus macrophylla, commonly known as Alemow, is a universal rootstock. Since this species is a rootstock, most of the researches done on it were came from the horticultural aspects such as cultural practices and the physical features. To the best of our knowledge, the current research is the first study on the fruit of Citrus macrophylla to evaluate its nutritional values. Therefore, elemental analysis of fruit is an important part to investigate in addition to determine the vitamin $\mathrm{C}$ content. Surveying literature, no element has been determined quantitatively in Citrus macrophylla except sodium and potassium in a single study and hence this result for metal analysis is to the best of our knowledge is new knowledge.

The obtained data are useful in evaluation of nutritional value of this species as an edible plant. The fruit of Citrus macrophylla is rich of vitamin C, which favors its nutritional value. The current investigated plant species is a good source of $\mathrm{Na}, \mathrm{K}, \mathrm{Ca}$ and $\mathrm{Mg}$. Fortunately, the concentrations of heavy metals such as $\mathrm{Cd}$ and $\mathrm{Pb}$ were found to be within the permissible limits for food to recommend as an edible plant. Accordingly, it is recommended using Citrus macrophylla the Alemow's fruit as an edible food although this species known only as a universal rootstock.

\section{Abbreviations}

GC-MS: Gas chromatography-mass spectrometry; GF-AAS: Graphite furnaceatomic absorption spectrometry; FAO/WHO: Food Agriculture Organization/ World Health Organization; DCPIP: 2,6-Dichlorophenolindophenol.

\section{Acknowledgements}

Authors gratefully acknowledge Technical Staff at Department of Chemistry, Faculty of Science, University of Khartoum, Sudan, and the Staff of the Chemical Laboratories of the Ministry of Mining, Sudan, for running samples in Atomic Absorption Spectrometer. In addition, authors gratefully acknowledge the staff at Department of Medicinal and Aromatic Plants Research, National Research Centre, Egypt, for running GC-MS analysis.

\section{Authors' contributions}

All authors certify that they have participated sufficiently in contributing to the intellectual content, concept, design of this work and writing the manuscript. AMAM (corresponding author) confirms that all listed authors have approved the manuscript before submission, including the names and order of authors, and that all authors receive the submission and all substantive correspondence with editors, as well as the full reviews. All authors read and approved the final manuscript. AMAM is the supervisor on the work and designed the experiments. MEM performed collection and authentication of plant materials. ASA performed extraction of essential oil and preparing all samples for analysis. NAA performed the experiments of physical properties. All authors read and approved the final manuscript.

\section{Funding}

This research received no specific grant from any funding agency in the public, commercial, or not-for-profit sectors.

Availability of data and materials

The datasets used and/or analyzed during the current study are available from the corresponding author on reasonable request.

\section{Declarations}

Ethics approval and consent to participate Not applicable.

Consent for publication Not applicable.

Competing interests

The authors declare that they have no competing interests. 


\begin{abstract}
Author details
1 Department of Chemistry, Rabigh College of Science \& Arts, King Abdulaziz University, PO Box 344, Rabigh 21911, Saudi Arabia. ${ }^{2}$ Department of Chemistry, Alzaiem Alazhari University, PO Box 1432, Khartoum North 13311, Sudan. ${ }^{3}$ Agricultural Research Corporation, Shambat Agricultural Research Station, PO Box 30, Khartoum North, Sudan. ${ }^{4}$ National Food Research Centre, PO Box 213, Khartoum North, Sudan.
\end{abstract}

Received: 12 October 2021 Accepted: 12 November 2021

Published online: 11 December 2021

\section{References}

Abbasi AM, Khan MA, Ahmad M, Zafar M, Khan H, Muhammad N, Sultana S (2009) Medicinal plants used for the treatment of jaundice and hepatitis based on socio-economic documentation. Afr J Biotechnol 9:1643-1650

Aguilar-Hernández MG, Sánchez-Bravo P, Hernández F, Carbonell-Barrachina AA, Pastor-Pérez JJ, Legua P (2020) Determination of the volatile profile of lemon peel oils as affected by rootstock Marlene. Foods 9:241-250

Anwar F, Naseer R, Bhanger Ml, Ashraf S, Talpur FN, Aladedunye FA (2008) Physico-chemical characteristics of Citrus seeds and seed oils from Pakistan. J Am Oil Chem Soc 85:321-330. https://doi.org/10.1007/ s11746-008-1204-3

Ani PN, Abel HC (2018) Nutrient, phytochemical, and anti-nutrient composition of Citrus maxima fruit juice and peel extract. Food Sci Nutr 6(3):653-658

AOAC (1990) Association of Official Analytical Chemists. Official methods of analysis. 15th edn. Arlington, Virginia, USA. https://law.resource.org/ pub/us/cfr/ibr/002/aoac.methods.1.1990.pdf

Arceusz A, Radecka I, Wesolowski M (2010) Identification of diversity in elements content in medicinal plants belonging to different plant families. Food Chem 120(1):52-58. https://doi.org/10.1016/j.foodchem. 2009.09.068

Azad AKM, Ali MA, Akter MS, Rahman J (2014) Isolation and characterization of pectin extracted from lemon pomace during ripening. J Food Nutr Sci 2(2):30-35. https://doi.org/10.11648/j.jfns.20140202.12

Beveridge T, Rao MA (1997) Juice extraction from apples and other fruits and vegetables. Crit Rev Food Sci Nutr 37(5):449-469. https://doi.org/ 10.1080/10408399709527784

Berezin OY, Tur'yan YI, Kuselman I, Shenhar A (1995) Alternative methods for titratable acidity determination. Talanta 42(4):507-517. https://doi.org/ 10.1016/0039-9140(95)01448-K

Castle WS, Nunnallee J, Manthey JA (2009) Screening Citrus rootstocks and related selections in soil and solution culture for tolerance to low-iron stress. HortScience 44(3):638-645. https://doi.org/10.21273/HORTSCI. 44.3.638

Czech A, Zarycka E, Yanovych D, Zasadna Z, Grzegorczyk I, Kłys S (2020) Mineral content of the pulp and peel of various Citrus fruit cultivars. Biol Trace Elem Res 193(2):555-563. https://doi.org/10.1007/ s12011-019-01727-1

Dharmawan J, Kasapis S, Curran P (2008) Characterization of volatile compounds in selected citrus fruits from Asia. Part II: peel oil. J Essent Oil Res 20(1):21-24. https://doi.org/10.1080/10412905.2008.9699411

El-Adawy TA, Rahma EH, El-Bedawy AA, Gafar AM (1999) Properties of some Citrus seeds. Part 1. Physicochemical characteristics of proteins. Nahrung (food) 43(9):374-378. https://doi.org/10.1002/(SICI)15213803(19991201)43:6\%3C374\%:AID-FOOD374\%3E3.0.CO;2-2

FAO/WHO (1984) Contaminants. In: Codex alimentarius. 1st edn., XVII. FAO/ WHO, Codex Alimentarius Commission, Rome. Italy. https://www.fao. org/3/at894e/at894e.pdf

FAO/WHO (2011) Working document for Information and use in discussion related to contaminants and toxins in the GSCTFF. Joint FAO/WHO Food Standards Programme Codex Committee on Contaminants in Foods. (Fifth Session), FAO/WHO, Codex Alimentarius Commission, The Hague, The Netherlands. https://www.fao.org/fao-who-codexalime ntarius/sh-proxy/en

Forner-Giner MA, Alcaide A, Primo-Millo E, Forner JB (2003) Performance of 'Navelina' orange on 14 rootstocks in Northern Valencia (Spain). Sci Hortic 98(3):223-232. https://doi.org/10.1016/S0304-4238(02)00227-3
Gebrelibanos M, Megersa N, Taddesse AM (2016) Levels of essential and non-essential metals in edible mushrooms cultivated in Haramaya, Ethiopia. Int J Food Contam 3(2):1-12. https://doi.org/10.1186/ s40550-016-0025-7

González-Mas MC, Rambla JL, López-Gresa MP, Blázquez MA, Granell A (2019) Volatile compounds in Citrus essential oils: a comprehensive review. Front Plant Sci 10(12):1-18. https://doi.org/10.3389/fpls.2019. 00012

Hamdan D, El-Readi MZ, Tahrani A, Herrmann F, Kaufmann D, Farrag N, ElShazly A, Wink M (2011) Chemical composition and biological activity of Citrus jambhiri Lush. Food Chem 127:394-403. https://doi.org/10. 1016/j.foodchem.2010.12.129

Legua P, Bellver R, Forner J, Forner-Giner MA (2011) Plant growth, yield and fruit quality of "Lane Late" navel orange on four Citrus rootstocks. Span J Agric Res 9(1):271-279. https://doi.org/10.5424/sjar/20110901-172-10

Levy Y, Lifshitz J (1995) Alemow (Citrus macrophylla Wester.), compared with six other rootstocks for nucellar "Minneola" tangelo (Citrus paradisi Macf. X Citrus reticulata Blanco). Sci Hortic 61:131-137. https://doi.org/ 10.1016/0304-4238(94)00735-X

Maimulyanti AP, Anton R (2016) Chemical composition of essential oil and hexane extract and antioxidant activity of various extracts of Acmella uliginosa (Sw.) Cass flowers from Indonesia. Agric Nat Resour 50(4):264-269. https://doi.org/10.1016/j.anres.2015.11.002

Mohammed AMA, Ibrahim AM, Omran AA, Mohamed ME, Elsheikh SEM (2013) Minerals content, essential oils composition and physicochemical properties of Citrus jambhiri Lush. (Rough Lemon) from the Sudan. Int Lett Chem Phys Astron 9(1):25-30. https://doi.org/10.18052/www. scipress.com/ILCPA.14.25

Mohamed ME, ElTayeb NM (2009) Citrus tristeza virus and its vectors in Northern Sudan, Bari CIHEAM, pp 131-134. https://om.ciheam.org/om/ pdf/b65/00801404.pdf

Navarra M, Mannucci C, Delbò M, Calapai G (2015) Citrus bergamia essential oil: From basic research to clinical application. Front Pharmacol 5(36):1-7. https://doi.org/10.3389/fphar.2015.00036

Nielsen SS (2010) Food analysis laboratory manual. 2nd edn., Chapter 7, p. 55, Springer, New York. https://doi.org/10.1007/978-1-4419-1463-7

Osendarp SJ, West CE, Black R (2003) The need for maternal zinc supplementation in developing countries: an unresolved issue. J Nutr 133:817-827. https://doi.org/10.1093/jn/133.3.8175

Paul DK, Shaha RK (2004) Nutrients, vitamins and minerals content in common Citrus fruits in the northern region of Bangladesh. Pak J Biol SC 7:283-242. https://doi.org/10.3923/pjbs.2004.238.242

Ranganna S (1986) Proximate analysis, color measurement and sensory evaluation. In: Handbook of analysis and quality control for fruit and vegetable products. 2nd edn. Tata McGraw-Hill Publishing Ltd., New Delhi.

Robbins PS, Alessandro RT, Stelinski LL, Lapointe SL (2012) Volatile profiles of young leaves of Rutaceae spp. varying in susceptibility to the Asian Citrus Psyllid (Hemiptera: Psyllidae). Fla Entomol 95(3):774-776. https:// doi.org/10.1653/024.095.0331

Saïdani M, Dhifi W, Marzouk B (2004) Lipid evaluation of some Tunisian Citrus seeds. J Food Lipids 11:242-250. https://doi.org/10.1111/j.17454522.2004.01136.x

Sharma RK, Agrawal M, Marshall FM (2009) Heavy metals in vegetables collected from production and market sites of a tropical urban area of India. Food Chem Toxicol 47:583-591. https://doi.org/10.1016/j.fct. 2008.12.016

Sheded GM, Pulford ID, Hamed IA (2006) Presence of major and trace elements in seven medicinal plants growing in the South-Eastern Desert, Egypt. J Arid Environ 66:210-217. https://doi.org/10.1016/j.jaridenv. 2005.10.022

Sian L, Krebs NF, Westcott JE (2002) Zinc homeostasis during lactation in a population with a low zinc intake. Am J Clin Nutr 75:99-103. https:// doi.org/10.1093/ajcn/75.1.99

Silalahi J (2002) Anticancer and health protective properties of citrus fruit components. Asia Pac J Clin Nutr 11(1):79-84. https://doi.org/10.1046/j. 1440-6047.2002.00271.x

Singh G, Singh O (2002) Chemistry of essential oils of Citrus species. Nat Prod Rad, 8-21. http://nopr.niscair.res.in/bitstream/123456789/ 12372/1/NPR\%201\%285\%29\%208-21.pdf 
Verzera A, Trozzi A, Gazea F, Cicciarello G, Cotroneo A (2003) Effects of rootstock on the composition of bergamot (Citrus bergamia Risso et Poiteau) essential oil. J Agric Food Chem 51:206-210. https://doi.org/ $10.1021 /$ jf0206872

Zouaghi G, Najar A, Aydi A, Claumann CA, Zibetti AW, BenMahmoud K, Jemmali A, Bleton J, Moussa F, Abderrabba M, Chammem N (2019) Essential oil components of Citrus cultivar 'Maltaise demi sanguine' (Citrus sinensis) as affected by the effects of rootstocks and viroid infection. Int J Food Prop 22:438-448. https://doi.org/10.1080/10942912. 2019.1588296

\section{Publisher's Note}

Springer Nature remains neutral with regard to jurisdictional claims in published maps and institutional affiliations.

\section{Submit your manuscript to a SpringerOpen ${ }^{\odot}$ journal and benefit from:}

- Convenient online submission

- Rigorous peer review

- Open access: articles freely available online

- High visibility within the field

- Retaining the copyright to your article

Submit your next manuscript at $\boldsymbol{\nabla}$ springeropen.com 